\title{
IMPLEMENTASI METODE FUZZY SERVQUAL DAN QUALITY FUNCTION DEPLOYPMENT TERHADAP KUALITAS LAYANAN BPJS KESEHATAN RSUP H. ADAM MALIK
}

\author{
Indah Simamora ${ }^{1)}$, Ratna Wahyuni ${ }^{2)}$ \\ ${ }^{1,2)}$ Universitas Quality Berastagi \\ e-mail: indahsimamora11@gmail.com
}

\begin{abstract}
ABSTRAK
Seiring dengan bertambahnya jumlah populasi manusia dan keadaan perekonomian yang semakin maju, maka kesadaran masyarakat terhadap kesehatan semakin meningkat. Ditambah lagi saat ini akses layanan Badan Penyelenggara Jaminan Sosial (BPJS) kesehatan semakin luas, Pihak rumah sakit harus dapat menambah kapasitas terhadap fasilitas - fasilitas yang ada dan meningkatkan kualitas pelayanan. Penelitian ini bertujuan mengimplementasikan metode Fuzzy Servqual dan Quality Function Deployment terhadap kualitas layanan BPJS Kesehatan RSUP H. Adam Malik dan menentukan atribut apa saja yang menjadi prioritas perbaikan. pengolahan data berdasarkan kriteria-kriteria metode Fuzzy-Servqual dengan menentukan fuzzy set, fuzzyfikasi dan defuzzyfikasi. menentuan Gap dan menentukan prioritas perbaikan dengan menggunakan metode Quality Function Deployment. Hasil penelitian ini menunjukkan bahwa keseluruhan 19 atribut layanan BPJS yang diberikan dengan menerapkan metode Fuzzy Servqual masih belum memenuhi harapan pasien, karena nilai kepuasan pasien terhadap layanan masih lebih rendah daripada nilai harapan. Atribut yang harus diprioritaskan untuk ditingkatkan kualitasnya, yaitu: Atribut Penyataan Q2 nilai gap -3.68, Atribut Penyataan Q7 dengan nilai gap -1.58., Atribut Penyataan Q12 dengan nilai gap -1.58. Respon teknis yang menjadi target utama adalah Pengadaan Training Service Excellent, Penambahan AC/Kipas Angin dalam ruangan pasien rawat inap, melakukan perbaikan terhadap sarana dan prasarana.
\end{abstract}

Kata Kunci: Fuzzy-Servqual, Quality Function Deploypment, Kualitas layanan, BPJS

\begin{abstract}
Along with the increase in the number of human population and economic conditions that are increasingly advanced, the public awareness of health is increasing. In addition, currently access to services for the Social Security Administering Agency (BPJS) is getting wider, the hospital must be able to add capacity to existing facilities and improve the quality of services. This study aims to implement the Fuzzy Servqual method and Quality Function Deployment on the quality of BPJS Health services in H. Adam Malik Hospital and determine which attributes are priority improvements. Data processing based on the criteria of the Fuzzy-Servqual method by determining fuzzy sets, fuzzyfication and defuzzyfication. determine the Gap and determine the priority of improvement using the Quality Function Deployment method. The results of this study indicate that all 19 BPJS service attributes provided by applying the Fuzzy Servqual method still do not meet patient expectations, because the value of patient satisfaction with services is still lower than the expectation value. Attributes that must be prioritized to improve their quality, namely: Revelation Attribute of $Q 2$ with a gap value -3.68, Revelation Attribute of $Q 7$ with a gap value of -1.58., Revelation Attribute of $Q 12$ with a gap value of -1.58 . The technical response that became the main target was the Procurement of Excellent Training Services, the addition of AC Fan in the inpatient room, making improvements to the facilities and infrastructure.
\end{abstract}

Keywords: Fuzzy-Servqual, Quality Function Deploypment, Service Quality, BPJS 


\section{PENDAHULUAN}

Keberadaan rumah sakit mutlak diperlukan karena setiap orang yang mengalami gangguan kesehatan pasti membutuhkan pengobatan dan salah satu penyedia layanan kesehatan adalah rumah sakit. Seiring dengan bertambahnya jumlah populasi manusia dan keadaan perekonomian yang semakin maju, maka kesadaran masyarakat terhadap kesehatan semakin meningkat. Hal ini dapat meningkatkan jumlah pengunjung suatu rumah sakit. Pihak rumah sakit harus dapat menambah kapasitas terhadap fasilitas - fasilitas yang ada. Selain penambahan kapasitas, pihak rumah sakit juga harus meningkatkan kualitas pelayanan yang diberikan. Hal ini bertujuan agar proses penanganan pasien bisa berjalan dengan cepat dan pasien dapat terlayani dengan baik.

Kualitas layanan merupakan perbandingan antara layanan yang dirasakan (persepsi) konsumen dengan kualitas layanan yang diharapkan konsumen. Jika kualitas layanan yang dirasakan sama atau melebihi kualitas layanan yang diharapkan, maka layanan dikatakan berkualitas dan memuaskan. Demikian halnya dengan kualitas pelayanan kesehatan di rumah sakit sangat dipengaruhi oleh interaksi antara pasien dengan rumah sakit. Perlu dilakukan pemahaman apa yang menjadi faktor utama pelanggan dalam menilai kualitas layanan kesehatan di rumah sakit, melalui pengukuran tingkat kepuasan pasien. Dengan demikian, dapat dilakukan upaya untuk meningkatkan kualitas layanan kesehatan sesuai dengan harapan pasien, (Perangin-angin, et. al., 2013).

Pelayanan yang optimal dalam dunia kesehatan adalah suatu hal yang sangat penting, karena disamping menyangkut masalah baik buruknya reputasi rumah sakit, juga menyangkut masalah nyawa dari pasien itu sendiri. RSUP H. Adam Malik merupakan salah satu instansi pusat yang bergerak pada pelayanan kesehatan. Usaha pelayanan RSUP H. Adam Malik meliputi rawat inap, rawat jalan, tindakan medis, obat-obatan dan alat kesehatan, penunjang diagnostik, penunjang medis, operasi dan pelayanan khusus seperti poliklinik, kacamata, persalinan dan Balai Kesehatan Masyarakat (Bakelmas).

Badan Penyelenggara Jaminan Sosial (BPJS) merupakan lembaga yang dibentuk untuk menyelenggarakan Program Program
Jaminan Sosial di Indonesia. Semakin luasnya akses layanan BPJS kesehatan, akan berpengaruh terhadap semakin banyaknya pasien akan yang akan berobat dengan menggunakan fasilitas BPJS di RSUP $\mathrm{H}$. Adam Malik. Kurangnya kualitas pelayanan menjadi salah satu kendala terhadap tingkat kepuasan pasien.

Salah satu metode pendekatan yang dipakai untuk mengukur kualitas pelayanan adalah konsep fuzzy servqual. Fuzzy Service Quality adalah Teori himpunan fuzzy yang memberikan sarana untuk mempresentasikan ketidakpastian dan merupakan alat untuk pemodelan ketidakpastian yang berhubungan dengan kesamaran, ketidakpastian dan kekurangan informasi mengenai elemenelementertentu dari problem yang dihadapi (kusumadewi et. al., 2010)

Usulan perbaikan yang diberikan merupakan hasil respon teknis dari metode Quality Function Deployment. Metode QFD merupakan suatu alat analisis untuk menjabarkan kebutuhan pelanggan, mengevaluasi produk atau secara sistematik mengenai kemampuannya memenuhi kebutuhan tersebut (Mehrjerdi, 2010). Beberapa penelitian tentang tentang analisis Servqual (Suharyanta et, al., 2012; Sutinah et, al., 2018).

Beberapa penelitian tentang tentang analisis Servqual dan Quality Function Deployment untuk meningkatkan kualitas pelayanan (Harijono et, al., 2011; Sianturi et, al., 2011; Yushila et, al., 2017).

\section{METODE PENELITIAN}

Penelitian ini adalah penelitian studi kasus dengan menggunakan data primer. Tahapan analisis yang digunakan untuk mencapai tujuan penelitian adalah

1. Identifikasi elemen penelitian servqual, yaitu tangibles, reliability, responsiveness, assurance, dan empathy (Yamit, 2010).

2. Pembuatan dan penyebaran kuesioner kepada pasien.

3. Melakukan uji Validitas dan Reliabilitas data.

4. Mengolah data berdasarkan kriteria-kriteria olah data pada metode Fuzzy-Servqual dengan 
menentukan fuzzy set, fuzzyfikasi dan defuzzyfikasi.

5. Menentukan nilai gap untuk melihat kesenjangan antara persepsi dan harapan.

6. Menentukan prioritas perbaikan dengan menggunakan metode Quality Function Deployment.

7. Pembuatan diagram cartesius metode IPA

8. Penyusunan House Of Quality

9. Membuat kesimpulan

Yang menjadi populasi dalam penelitian ini adalah seluruh pasien yang menggunakan layanan BPJS Kesehatan, baik yang sudah pernah berobat maupun yang baru pertama kali berobat di RSUP. Adam malik.
Jumlah populasi pada penelitian ini pada bulan Mei -Juni sebanyak 3.068 pasien.

Dalam penelitian ini yang menjadi sampel adalah pasien yang menggunakan layanan BPJS yang datang berobat ke RSUP. Adam Malik. Untuk menentukan jumlah sampel, peneliti menggunakan pendapat dari Slovin yaitu: 96,84. Agar mendapatkan hasil data yang lebih akurat, maka jumlah responden yang akan dijadikan sampel dan digenapkan menjadi 100 responden.

Uji validitas dilakukan dengan menghitung nilai korelasi antara skor masingmasing pernyataan dengan skor total dengan keseluruhan 19 atribut pernyataan dengan menggunakan software SPSS versi 16.00.

Tabel 1. Variabel Pernyataan.

\begin{tabular}{|c|c|c|}
\hline No. Question & $\begin{array}{l}\text { Dimensi } \\
\text { Servqual }\end{array}$ & Variabel Pernyataan Kualitas Pelayanan \\
\hline Q1 & \multirow{5}{*}{$\begin{array}{l}\text { Tangibles (Bukti } \\
\text { Fisik) }\end{array}$} & $\begin{array}{l}\text { Setiap ruangan yang didatangi pasien dalam keadaan } \\
\text { bersih }\end{array}$ \\
\hline Q2 & & $\begin{array}{l}\text { Kelengkapan AC/Kipas angin di dalam ruangan } \\
\text { pasien }\end{array}$ \\
\hline Q3 & & $\begin{array}{l}\text { Penampilan petugas kesehatan terlihat bersih dan } \\
\text { rapih }\end{array}$ \\
\hline Q4 & & Fasilitas di ruang tunggu sudah modern \\
\hline Q5 & & Rumah sakit memiliki peralatan medis yang lengkap \\
\hline Q6 & \multirow{4}{*}{$\begin{array}{l}\text { Reliability } \\
\text { (Keandalan) }\end{array}$} & $\begin{array}{l}\text { Petugas kesehatan memberitahu dengan jelas penyakit } \\
\text { pasien }\end{array}$ \\
\hline Q7 & & Perawat sangat handal dalam melayani pasien \\
\hline Q8 & & $\begin{array}{l}\text { Petugas kesehatan menjelaskan dengan benar pada } \\
\text { keluarga cara merawat pasien }\end{array}$ \\
\hline Q9 & & $\begin{array}{l}\text { Petugas kesehatan mendiagnosa penyakit pasien } \\
\text { dengan dengan akurat dan menemukan solusinya. }\end{array}$ \\
\hline Q10 & \multirow{4}{*}{$\begin{array}{l}\text { Responsiveness } \\
\text { (Daya Tanggap) }\end{array}$} & $\begin{array}{l}\text { Petugas kesehatan sangat tanggap terhadap keluhan } \\
\text { pasien }\end{array}$ \\
\hline Q11 & & $\begin{array}{l}\text { Bagian pendaftaran dengan cepat melayani antrian } \\
\text { pasien }\end{array}$ \\
\hline Q12 & & $\begin{array}{l}\text { Perawat bersikap ramah dan sopan dalam } \\
\text { menjalankan tugasnya }\end{array}$ \\
\hline Q13 & & $\begin{array}{l}\text { Petugas kesehatan mau mendengarkan pertanyaan } \\
\text { pasien mengenai penyakit yang diderita pasien }\end{array}$ \\
\hline Q14 & \multirow{3}{*}{$\begin{array}{l}\text { Assurance } \\
\text { (Jaminan) }\end{array}$} & $\begin{array}{l}\text { Petugas kesehatan sudah berpengalaman mengobati } \\
\text { pasien }\end{array}$ \\
\hline Q15 & & Lingkungan rumah sakit terasa nyaman dan tentram \\
\hline Q16 & & $\begin{array}{l}\text { Petugas kesehatan memiliki kemampuan dan } \\
\text { pengetahuan dalam mengobati pasien }\end{array}$ \\
\hline
\end{tabular}




\begin{tabular}{|c|l|l|}
\hline \multirow{2}{*}{ Q17 } & \multirow{2}{*}{$\begin{array}{l}\text { Empathy } \\
\text { (Empati) }\end{array}$} & $\begin{array}{l}\text { Petugas kesehatan perhatian pada saat pengobatan } \\
\text { berlangsung }\end{array}$ \\
& & $\begin{array}{l}\text { Petugas kesehatan berkomunikasi dengan bahasa } \\
\text { yang mudah dimengerti }\end{array}$ \\
\cline { 1 - 1 } & & $\begin{array}{l}\text { Petugas kesehatan minta maaf atas pelayanan yang } \\
\text { kurang baik. }\end{array}$ \\
\hline
\end{tabular}

Hasil uji validitas untuk 19 atribut adalah semua atribut valid karena $r$ tingkat kepentingan dan $\mathrm{r}$ tingkat kepuasan lebih besar dari $r$ tabel yaitu 0,195 . Hasil uji reliabilitas kuisioner formal dengan menggunakan software SPSS 16.00 diperoleh $\alpha_{\text {TingkatKepentingan }}=0,967$ dan $\alpha_{\text {TingkatKepuasan }}=0,883$. Jadi data tersebut sudah reliabel karena nilai kuesioner dianggap reliabel karena $\alpha>0,60$.

\section{HASIL DAN PEMBAHASAN Hasil Rekapitulasi skor persepsi}

Hasil rekapitulasi skor dari data persepsi didapat dari penjumlahan setiap skor jawaban responden. Dengan kriteria dan skor sebagai berikut:

1. Kriteria penilaian dan skor dari harapan/ekspektasi adalah sebagai berikut:

a. Sangat tidak penting $(\mathrm{STP})=1$

b. Tidak Penting $(\mathrm{TP})=2$

c. Cukup Penting $(\mathrm{CP})=3$

d. Penting $(\mathrm{P})=4$

e. Sangat Penting $(\mathrm{SP})=5$

2. Kriteria penilaian dan skor dari persepsi adalah sebagai berikut:

a. Sangat Tidak Puas $(\mathrm{STP})=1$

b. Tidak Puas $(\mathrm{TP})=2$

c. Cukup Puas $(\mathrm{CP})=3$

d. Puas $(\mathrm{P})=4$

e. Sangat Puas $(\mathrm{SP})=5$.

Tabel 2. Hasil Rekapitulasi Skor Persepsi

\begin{tabular}{|l|r|r|r|r|r|r|}
\hline \multirow{2}{*}{ Pernyataan } & $\begin{array}{c}\text { Sangat } \\
\text { Tidak } \\
\text { Puas }\end{array}$ & $\begin{array}{c}\text { Cukup } \\
\text { Puas }\end{array}$ & \multicolumn{1}{c|}{ Puas } & \multicolumn{1}{c|}{$\begin{array}{c}\text { Sangat } \\
\text { Puas }\end{array}$} & \multicolumn{1}{c|}{$\begin{array}{c}\text { Sangat } \\
\text { Puas }\end{array}$} & \multirow{2}{*}{ Total } \\
\cline { 2 - 6 } Q1 & $\mathbf{1}$ & $\mathbf{2}$ & $\mathbf{3}$ & \multicolumn{1}{|c|}{$\mathbf{4}$} & \multicolumn{1}{c}{$\mathbf{5}$} & \\
\hline Q2 & 0 & 0 & 6 & 70 & 24 & 100 \\
\hline Q3 & 28 & 12 & 18 & 30 & 12 & 100 \\
\hline Q4 & 0 & 0 & 8 & 65 & 27 & 100 \\
\hline Q5 & 0 & 3 & 18 & 60 & 19 & 100 \\
\hline Q6 & 0 & 0 & 29 & 51 & 20 & 100 \\
\hline Q7 & 0 & 4 & 10 & 70 & 16 & 100 \\
\hline Q8 & 0 & 2 & 22 & 68 & 8 & 100 \\
\hline Q9 & 0 & 4 & 14 & 70 & 12 & 100 \\
\hline Q10 & 0 & 0 & 11 & 71 & 18 & 100 \\
\hline Q11 & 3 & 16 & 20 & 48 & 12 & 100 \\
\hline Q12 & 3 & 11 & 25 & 44 & 17 & 100 \\
\hline Q13 & 0 & 8 & 14 & 60 & 18 & 100 \\
\hline Q14 & 0 & 7 & 13 & 67 & 13 & 100 \\
\hline Q15 & 0 & 0 & 13 & 75 & 12 & 100 \\
\hline Q16 & 0 & 0 & 10 & 78 & 12 & 100 \\
\hline Q17 & 0 & 0 & 11 & 72 & 17 & 100 \\
\hline Q18 & 0 & 0 & 6 & 74 & 20 & 100 \\
\hline Q19 & 8 & 4 & 6 & 68 & 14 & 100 \\
\hline
\end{tabular}


Tabel 3. Hasil Rekapitulasi Skor Persepsi

\begin{tabular}{|l|c|c|c|c|c|c|}
\hline \multirow{2}{*}{ Pernyataan } & $\begin{array}{c}\text { Sangat } \\
\text { Tidak } \\
\text { Puas }\end{array}$ & $\begin{array}{c}\text { Cukup } \\
\text { Puas }\end{array}$ & Puas & $\begin{array}{c}\text { Sangat } \\
\text { Puas }\end{array}$ & $\begin{array}{c}\text { Sangat } \\
\text { Puas }\end{array}$ & \multirow{2}{*}{ Total } \\
\cline { 2 - 6 } & $\mathbf{1}$ & $\mathbf{2}$ & $\mathbf{3}$ & $\mathbf{4}$ & $\mathbf{5}$ & \\
\hline Q1 & 0 & 0 & 0 & 36 & 64 & 100 \\
\hline Q2 & 0 & 0 & 0 & 30 & 70 & 100 \\
\hline Q3 & 0 & 0 & 0 & 32 & 68 & 100 \\
\hline Q4 & 0 & 0 & 0 & 20 & 80 & 100 \\
\hline Q5 & 0 & 0 & 0 & 46 & 54 & 100 \\
\hline Q6 & 0 & 0 & 0 & 62 & 38 & 100 \\
\hline Q7 & 0 & 0 & 0 & 52 & 48 & 100 \\
\hline Q8 & 0 & 0 & 0 & 54 & 46 & 100 \\
\hline Q9 & 0 & 0 & 0 & 44 & 56 & 100 \\
\hline Q10 & 0 & 0 & 0 & 60 & 40 & 100 \\
\hline Q11 & 0 & 0 & 4 & 50 & 46 & 100 \\
\hline Q12 & 0 & 0 & 0 & 52 & 48 & 100 \\
\hline Q13 & 0 & 0 & 0 & 80 & 20 & 100 \\
\hline Q14 & 0 & 0 & 0 & 53 & 47 & 100 \\
\hline Q15 & 0 & 0 & 0 & 60 & 40 & 100 \\
\hline Q16 & 0 & 0 & 0 & 74 & 26 & 100 \\
\hline Q17 & 0 & 0 & 0 & 52 & 48 & 100 \\
\hline Q18 & 0 & 0 & 0 & 50 & 50 & 100 \\
\hline Q19 & 0 & 0 & 0 & 62 & 38 & 100 \\
\hline
\end{tabular}

\section{Penentuan Fuzzy Set}

Penentuan Fuzzy Set ini dilakukan untuk menentukan skor dari jawaban responden berdasarkan beberapa kriteria, yaitu Sangat Tidak Baik, Tidak Baik, Cukup Baik, Baik, Sangat Baik. Berikut ini adalah cara penentuan fuzzy set dengan gambar 1 :

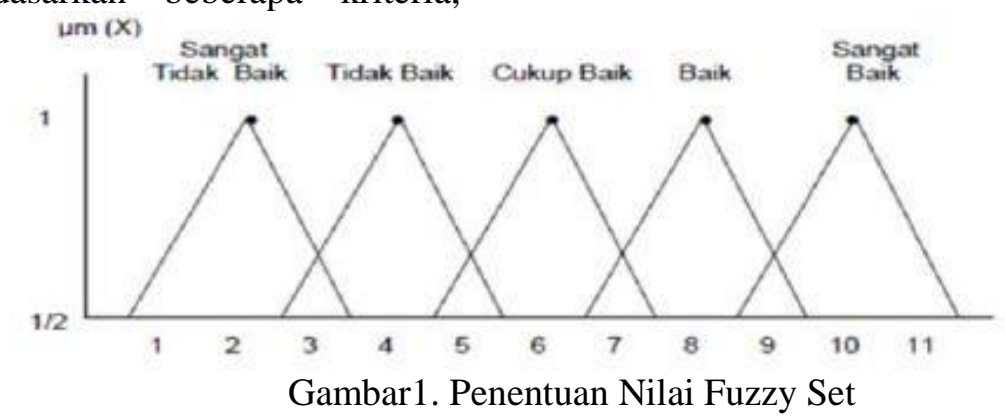

Sumber: (Suharyanta \& A'yunin, 2012

\section{Fuzzyfikasi}

Pada tahap ini perhitungan fuzzyfikasi dilakukan untuk mendapatkan nilai batas bawah (c), batas tengah (a), dan batas atas (b) yang merupakan nilai dari Triangular Fuzzy Number (TFN) pada tabel 4. dan tabel 5. . 
Tabel 4. Hasil Fuzzy Persepsi

\begin{tabular}{|c|c|c|c|}
\hline \multirow{2}{*}{$\begin{array}{c}\text { No. } \\
\text { Pernyataan }\end{array}$} & \multicolumn{3}{|c|}{ TFN } \\
\cline { 2 - 4 } Q1 & 7,36 & 8,86 & a \\
\hline Q2 & 4,72 & 6,22 & 7,72 \\
\hline Q3 & 7,38 & 8,88 & 10,38 \\
\hline Q4 & 6,9 & 8,4 & 9,9 \\
\hline Q5 & 6,82 & 8,32 & 9,82 \\
\hline Q6 & 6,96 & 8,46 & 9,96 \\
\hline Q7 & 6,64 & 8,14 & 9,64 \\
\hline Q8 & 6,8 & 8,3 & 9,8 \\
\hline Q9 & 7,14 & 8,64 & 10,14 \\
\hline Q10 & 5,96 & 7,46 & 8,96 \\
\hline Q11 & 6,26 & 7,76 & 9,26 \\
\hline Q12 & 6,22 & 7,72 & 9,22 \\
\hline Q13 & 6,76 & 8,26 & 9,76 \\
\hline Q14 & 6,72 & 8,22 & 9,72 \\
\hline Q15 & 6,98 & 8,48 & 9,98 \\
\hline Q16 & 7,04 & 8,54 & 10,04 \\
\hline Q17 & 7,12 & 8,62 & 10,12 \\
\hline Q18 & 7,28 & 8,78 & 10,28 \\
\hline Q19 & 6,52 & 8,02 & 9,52 \\
\hline & & & \\
\hline
\end{tabular}

Tabel 5. Hasil Fuzzy Harapan

\begin{tabular}{|c|r|r|r|}
\hline \multirow{2}{*}{ Nornyatan } & \multicolumn{3}{|c|}{ TFN } \\
\cline { 2 - 4 } & \multicolumn{1}{|c|}{ c } & \multicolumn{1}{c|}{ a } & \multicolumn{1}{c|}{ b } \\
\hline Q1 & 8,28 & 9,78 & 11,28 \\
\hline Q2 & 8,4 & 9,9 & 11,4 \\
\hline Q3 & 8,36 & 9,86 & 11,36 \\
\hline Q4 & 8,6 & 10,1 & 11,6 \\
\hline Q5 & 8,08 & 9,58 & 11,08 \\
\hline Q6 & 7,76 & 9,26 & 10,76 \\
\hline Q7 & 7,96 & 9,46 & 10,96 \\
\hline Q8 & 7,92 & 9,42 & 10,92 \\
\hline Q9 & 8,12 & 9,62 & 11,12 \\
\hline Q10 & 7,8 & 9,3 & 10,8 \\
\hline Q11 & 7,84 & 9,34 & 10,84 \\
\hline Q12 & 7,96 & 9,46 & 10,96 \\
\hline Q13 & 7,4 & 8,9 & 10,4 \\
\hline Q14 & 7,94 & 9,44 & 10,94 \\
\hline Q15 & 7,8 & 9,3 & 10,8 \\
\hline Q16 & 7,52 & 9,02 & 10,52 \\
\hline
\end{tabular}




\begin{tabular}{|r|r|r|r|}
\hline Q17 & 7,96 & 9,46 & 10,96 \\
\hline Q18 & 8 & 9,5 & 11 \\
\hline Q19 & 7,76 & 9,26 & 10,76 \\
\hline
\end{tabular}

\section{Defuzzyfikasi}

Tahap selanjutnya adalah menghitung nilai Defuzzyfikasi dari persepsi dan harapan. Defuzzyfikasi ini dilakukan untuk mendapatkan nilai tunggal yang representatif. Tabel 6 contoh perhitungan defuzzyfikasi

untuk tingkat persepsi pada variabel pernyataan Q1 dengan menggunakan rumus Arithmatic Mean Yaitu

$\mu A \cap B=(\mu A[x]+\mu B[x]) / 2$

$\mu A \cap B=\frac{8.86+10.36}{2}=\frac{19.22}{2}=9.61$

Tabel 6. Hasil Defuzzyfikasi Persepsi

\begin{tabular}{|c|c|c|}
\hline $\begin{array}{c}\text { No. } \\
\text { Pernyataan }\end{array}$ & $\begin{array}{c}\text { Defuzzyfikasi } \\
\text { Persepsi }\end{array}$ & $\begin{array}{c}\text { Defuzzyfikasi } \\
\text { Harapan }\end{array}$ \\
\hline Q1 & 9,61 & 10,53 \\
\hline Q2 & 6,97 & 10,65 \\
\hline Q3 & 9,63 & 10,61 \\
\hline Q4 & 9,15 & 10,85 \\
\hline Q5 & 9,07 & 10,33 \\
\hline Q6 & 9,21 & 10,01 \\
\hline Q7 & 8,89 & 10,21 \\
\hline Q8 & 9,05 & 10,17 \\
\hline Q9 & 9,39 & 10,37 \\
\hline Q10 & 8,21 & 10,05 \\
\hline Q11 & 8,51 & 10,09 \\
\hline Q12 & 8,47 & 10,21 \\
\hline Q13 & 9,01 & 9,65 \\
\hline Q14 & 8,97 & 10,19 \\
\hline Q15 & 9,23 & 10,05 \\
\hline Q16 & 9,29 & 9,77 \\
\hline Q17 & 9,37 & 10,21 \\
\hline Q18 & 9,53 & 10,25 \\
\hline Q19 & 8,77 & 10,01 \\
\hline
\end{tabular}

Hasil Perhitungan Nilai Gap per Variabel Pernyataan
Nilai gap per variabel pernyataan didapat pada tabel 7 berdasarkan selisih dari nilai persepsi dan nilai harapan. 
Tabel 7. Nilai Gap Persepsi dan Harapan Pelanggan

\begin{tabular}{|c|c|c|c|c|}
\hline $\begin{array}{l}\text { Dimensi } \\
\text { Servqual }\end{array}$ & $\begin{array}{c}\text { No. } \\
\text { pernyataan }\end{array}$ & $\begin{array}{c}\text { Defuzzzyfikasi } \\
\text { Persepsi }\end{array}$ & $\begin{array}{c}\text { Defuzzzyfikasi } \\
\text { Harapan }\end{array}$ & GAP \\
\hline \multirow{5}{*}{$\begin{array}{c}\text { Tangibles } \\
\text { (Bukti Fisik) }\end{array}$} & $\overline{\mathrm{Q} 1}$ & 9,61 & 10,53 & $-0,92$ \\
\hline & Q2 & 6,97 & 10,65 & $-3,68$ \\
\hline & Q3 & 9,63 & 10,61 & $-0,98$ \\
\hline & Q4 & 9,15 & 10,85 & $-1,7$ \\
\hline & Q5 & 9,07 & 10,33 & $-1,26$ \\
\hline \multirow{4}{*}{$\begin{array}{c}\text { Reliability } \\
\text { (Keandalan) }\end{array}$} & Q6 & 9,21 & 10,01 & $-0,8$ \\
\hline & Q7 & 8,89 & 10,21 & $-1,32$ \\
\hline & Q8 & 9,05 & 10,17 & $-1,12$ \\
\hline & Q9 & 9,39 & 10,37 & $-0,98$ \\
\hline \multirow{4}{*}{$\begin{array}{c}\text { Responsivenes } \\
\text { s (Daya } \\
\text { Tanggap) }\end{array}$} & Q10 & 8,21 & 10,05 & $-1,84$ \\
\hline & Q11 & 8,51 & 10,09 & $-1,58$ \\
\hline & Q12 & 8,47 & 10,21 & $-1,74$ \\
\hline & Q13 & 9,01 & 9,65 & $-0,64$ \\
\hline \multirow{3}{*}{$\begin{array}{l}\text { Assurance } \\
\text { (Jaminan) }\end{array}$} & Q14 & 8,97 & 10,19 & $-1,22$ \\
\hline & Q15 & 9,23 & 10,05 & $-0,82$ \\
\hline & Q16 & 9,29 & 9,77 & $-0,48$ \\
\hline \multirow{3}{*}{$\begin{array}{l}\text { Empathy } \\
\text { (Empati) }\end{array}$} & Q17 & 9,37 & 10,21 & $-0,84$ \\
\hline & Q18 & 9,53 & 10,25 & $-0,72$ \\
\hline & Q19 & 8,77 & 10,01 & $-1,24$ \\
\hline
\end{tabular}

\section{Pembuatan Diagram Kartesius Metode IPA}

Tahap selanjutnya adalah membuat diagram Kartesius untuk menghubungkan tingkat kepuasan/persepsi dengan tingkat harapan pelanggan. Pada tahap ini ditempatkan 19 atribut layanan yang bernilai negatif kedalam diagram Kartesius, dengan menggunakan nilai rata-rata kepuasan/persepsi dan harapan pelanggan tiap atribut layanan. Titik perpotongan yang dipakai adalah rata-rata persepsi dan harapan pelanggan untuk seluruh atribut. Plotting gap dilakukan untuk mengetahui atribut layanan yang benar-benar harus diprioritaskan peningkatan kualitas layanannya. Gap atribut layanan yang ditunjukkan pada gambar 1, yang terletak pada kuadran IV adalah atribut layanan yang harus ditingkatkan terlebih dahulu. 


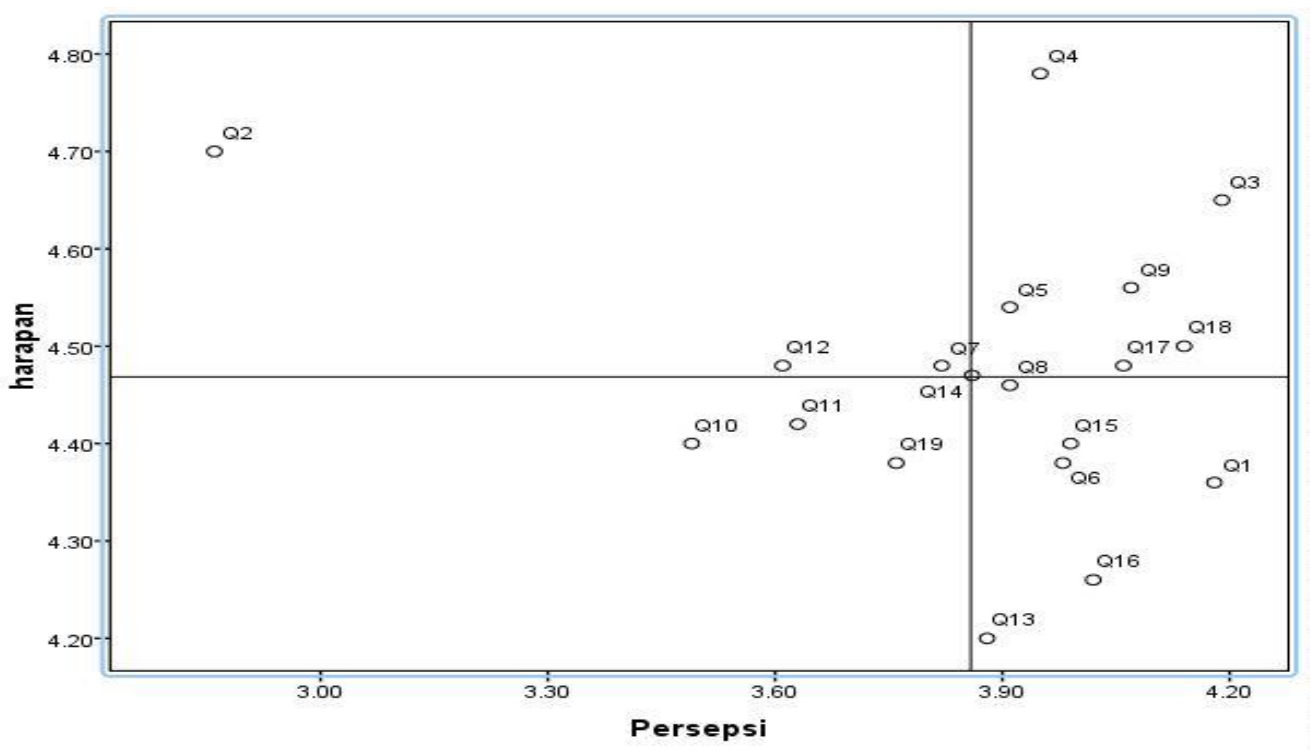

Gambar 1. Diagram Kartesius Tingkat Harapan-Tingkat Kepuasan

Pada gambar 1, dari sembilan belas atribut layanan hanya tiga yang berada pada kuadran IV dan akan menjadi customer needs pada penyusunan HoQ pada metode QFD selanjutnya. Atribut layanan yang diprioritaskan untuk mendapatkan perbaikan adalah:

- Atribut Penyataan Q2, yaitu Kelengkapan AC/Kipas angin di dalam ruangan pasien.

- Atribut Penyataan Q7, yaitu Perawat sangat handal dalam melayani pasien.

- Atribut Penyataan Q12, Perawat bersikap ramah dan sopan dalam menjalankan tugasnya
Penyusunan House Of Quality (HoQ)

Pada tahap ini dilakukan penghitungan dan pengumpulan komponen-komponen penyusun $\mathrm{HoQ}$, namun hanya bagi atribut layanan yang mendapat prioritas untuk ditingkatkan kualitasnya. Komponenkomponen penyusun $\mathrm{HoQ}$, adalah:

1. Customer Needs

Bagian customer needs adalah empat atribut layanan prioritas yang terdapat pada kuadran IV diagram Kartesius.

\section{Planning Matrix}

Terdapat enam macam data penyusun planning matrix yang ditunjukkan pada tabel 8 berikut.

Tabel 8. Komponen Planning Matrix

\begin{tabular}{|c|c|c|c|c|c|c|c|}
\hline \multirow[b]{2}{*}{ No. } & \multicolumn{2}{|c|}{ Rata-rata } & \multirow[b]{2}{*}{ Goal } & \multirow{2}{*}{$\begin{array}{c}\text { Improv } \\
\text { ement } \\
\text { Ratio }\end{array}$} & \multirow[b]{2}{*}{$\begin{array}{l}\text { Sales } \\
\text { point }\end{array}$} & \multirow[b]{2}{*}{$\begin{array}{c}\text { Raw } \\
\text { Weight }\end{array}$} & \multirow{2}{*}{$\begin{array}{l}\text { Normalized } \\
\text { Raw Weight }\end{array}$} \\
\hline & Harapan & Persepsi & & & & & \\
\hline Q2 & 4.7 & 2.86 & 4.50 & 1.57 & 1.5 & 11.07 & 0.397 \\
\hline Q7 & 4.48 & 3.82 & 4.50 & 1.18 & 1.5 & 7.93 & 0.285 \\
\hline Q12 & 4.48 & 3.61 & 4.50 & 1.25 & 1.5 & 8.4 & 0.301 \\
\hline
\end{tabular}

\section{Technical Response}

Bagian technical response yang ditunjukkan pada tabel 9, merupakan tanggapan atau solusi yang diberikan oleh pihak manajemen RKZ dalam memenuhi kebutuhan pelanggan.

\section{Relationship}

Nilai relationship yang ditunjukkan pada tabel 10, menjelaskan hubungan antara customer needs dengan technical response. Semakin besar nilai relationship menunjukkan hubungan antara customer needs dengan technical response yang semakin kuat.

\section{Technical Correlations}

Technical correlations menjelaskan hubungan antar technical response. Hubungan 
ini perlu diperhatikan karena ada kemungkinan respon teknis satu dengan yang lain mempunyai hubungan saling menunjang, atau sebaliknya respon teknis yang satu dapat menghambat respon teknis yang lain, sehingga pelaksanaannya harus lebih diperhatikan lagi.

\section{Technical Matrix}

Technical matrix yang ditunjukkan pada tabel 11 berisi tiga informasi. Nilai contribution yang tinggi menunjukkan bahwa respon teknis tersebut akan memberikan pengaruh yang besar terhadap peningkatan kualitas layanan. Respon teknis dengan nilai normalized contribution tertinggi akan diprioritaskan untuk ditingkatkan kualitas layanannya.

Tabel 9. Technical Response

\begin{tabular}{|l|l|l|}
\hline & \multicolumn{1}{|c|}{ Voice Of Customer } & \multicolumn{1}{|c|}{ Technical Response } \\
\hline Q2 & $\begin{array}{l}\text { Kelengkapan AC/Kipas angin dalam ruangan pasien } \\
\text { rawat inap. }\end{array}$ & $\begin{array}{l}\text { Penambahan AC/Kipas } \\
\text { Angin dalam ruangan } \\
\text { pasien rawat inap }\end{array}$ \\
\cline { 3 - 3 } & $\begin{array}{l}\text { Melakukan perbaikan } \\
\text { terhadap sarana dan } \\
\text { prasarana. }\end{array}$ \\
\hline Q7 & Perawat sangat handal dalam melayani keluhan pasien & $\begin{array}{l}\text { Pengadaan Training } \\
\text { Service Excellent }\end{array}$ \\
\hline
\end{tabular}

Tabel 10. Nilai Relationship

\begin{tabular}{|c|c|c|c|c|}
\hline No. & $\begin{array}{l}\text { Customer } \\
\text { Needs }\end{array}$ & $\begin{array}{c}\text { Penambahan } \\
\text { AC/Kipas Angin } \\
\text { dalam ruangan } \\
\text { pasien rawat } \\
\text { inap }\end{array}$ & $\begin{array}{c}\text { Melakukan } \\
\text { perbaikan terhadap } \\
\text { sarana dan } \\
\text { prasarana }\end{array}$ & $\begin{array}{c}\text { Pengadaan } \\
\text { Training Service } \\
\text { Excellent }\end{array}$ \\
\hline Q2 & $\begin{array}{l}\text { Kelengkapan } \\
\text { AC/Kipas } \\
\text { angin dalam } \\
\text { ruangan } \\
\text { pasien rawat } \\
\text { inap }\end{array}$ & 9 & 9 & \\
\hline Q7 & $\begin{array}{l}\text { Perawat } \\
\text { sangat handal } \\
\text { dalam } \\
\text { melayani } \\
\text { keluhan } \\
\text { pasien }\end{array}$ & & & 9 \\
\hline Q12 & $\begin{array}{l}\text { Perawat } \\
\text { bersikap } \\
\text { ramah dan } \\
\text { sopan dalam } \\
\text { menjalankan }\end{array}$ & & & 9 \\
\hline
\end{tabular}




\begin{tabular}{|l|l|l|l|l|}
\hline & tugasnya & & & \\
\hline
\end{tabular}

Tabel 11. Technical Matrix

\begin{tabular}{|l|c|c|c|}
\hline Technical Response & Contribution & $\begin{array}{c}\text { Normalized } \\
\text { Contribution }\end{array}$ & Target \\
\hline $\begin{array}{l}\text { Penambahan AC/Kipas Angin } \\
\text { dalam ruangan } \\
\text { pasien rawat inap }\end{array}$ & 3.57 & 0.29 & 2 \\
\hline $\begin{array}{l}\text { Melakukan } \\
\text { perbaikan terhadap } \\
\text { sarana dan prasarana }\end{array}$ & 3.57 & 0.29 & 2 \\
\hline $\begin{array}{l}\text { Pengadaan Training } \\
\text { Service Excellent }\end{array}$ & 5.274 & 0.42 & 1 \\
\hline
\end{tabular}

Hasil dari penggabungan enam adalah House of Quality (HoQ) yang komponen-komponen penyusun tersebut ditunjukkan pada gambar 3.

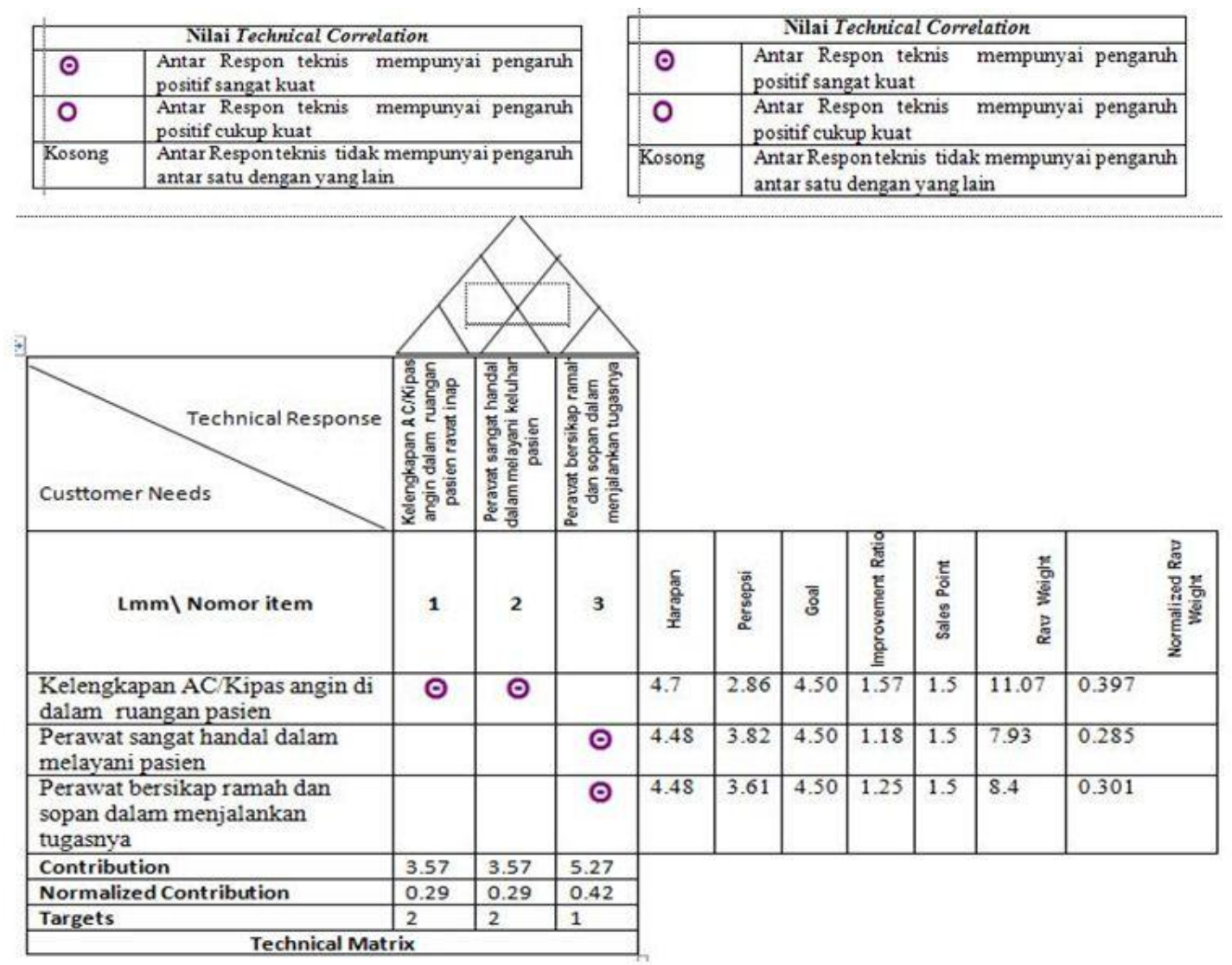

Gambar 3. House of Quality (HoQ).

\section{SIMPULAN DAN SARAN}

Hasil pengukuran gap dengan metode

Fuzzy Servqual menunjukkan bahwa keseluruhan 19 atribut layanan BPJS rumah sakit RSUP. Adam Malik yang diberikan masih belum memenuhi harapan pasien, karena nilai kepuasan pasien terhadap layanan masih lebih rendah daripada nilai harapan. Hasil analisis dengan menggunakan diagram Kartesius menunjukkan 4 atribut layanan yang harus diprioritaskan untuk ditingkatkan kualitasnya, yaitu: Atribut Penyataan Q2, yaitu Kelengkapan AC/Kipas angin di dalam ruangan pasien dengan nilai gap -3,68, Atribut 
Penyataan Q7, yaitu Perawat sangat handal dalam melayani pasien dengan nilai gap 1,32. , Atribut Penyataan Q12, Perawat bersikap ramah dan sopan dalam menjalankan Tugasnya dengan nilai gap $-1,58$. Hasil dari penyusunan House of Quality (HoQ) menunjukkan 3 kegiatan yang harus dilakukan untuk meningkatkan kualitas layanan BPJS rumah sakit RSUP. Adam Malik, yaitu: Pengadaan Training Service Excellent, Penambahan AC/Kipas Angin dalam ruangan pasien rawat inap dan Melakukan perbaikan terhadap sarana dan prasarana.

\section{DAFTAR PUSTAKA}

Harijono, H \& Bobby, O.P.S. (2011). Upaya Peningkatan Kalitas layanan Farmasi RSK. ST Vincentius A Paulo Surabaya dengan Menggunakan Metode Servqual dan QFD. Prosiding Seminar Nasional Manajemen Teknologi XIV.

Kusumadewi, S \& Purnomo, H. (2010). Aplikasi Logika Fuzzy untuk pendukung keputusan. Yogyakarta: Graha Ilmu.

Mehrjerdi, Y, Z. (2010). Quality Function Deploymennt and Its Extension. International Journal of Quality \& Reliability Management, 27(6), 616-640.

Perangin-Angin, R.,Nababan, E.S.M, \& Bu'ulolo, F. (2013). Strategi peningkatan kualitas pelayanan kesehatan menggunakan Integrasi metode fuzzy servqual (studi kasus: rsu vina estetica medan). Saintia Matematika; Medan.
Saran dalam penelitian ini adalah dalam peningkatan pelayanan pada pasien, hasil penelitian ini dapat dijadikan bahan pertimbangan pihak rumah sakit RSUP. Adam Malik untuk memperbaiki kualitas pelayanan.

\section{UCAPAN TERIMAKASIH}

Riset penulis dibiayai oleh Hibah Penelitian Dosen Pemula dari Direktorat Riset dan Pengabdian Masyarakat (DRPM) Ristekdikti dengan kontrak penelitian No: T/49/L1.3.1/PT.01.03/2019.

Sianturi, H, P \& Moses, L, S (2011). Peningkatan Kualitas Pelayanan Kesehatan Pasien Unit Instalasi Rawat Jalan (IRJ) Rumkit AL DR Ramelan Surabaya dengan menggunakan Metode Servqual dan QFD. Surabaya: Prosiding Seminar Nasional Manajemen Teknologi XIV

Suharyanta \& A'yunin, Q. (2012). Analisis Tingkat Kualitas Pelayanan Jasa Menggunakan Metode Service Quality (Servqual) Fuzzzy di Instalasi Radiologi Rumah Sakit Umum Daerah (RSUD) Panembahen Senopati Bantul. KESMAS, 7(1), 27-50.

Sutinah, E. \& Simamora, O, R. (2018). Metode Fuzzy Servqual dalam Mengukur Kepuasan Pasien terhadap Kualitas Layanan BPJS Kesehatan. Jurnal Informatika, 5(1), 90-101. 